\title{
Genome-wide analysis of gynecologic cancer: The Cancer Genome Atlas in ovarian and endometrial cancer (Review)
}

\author{
MOITO IIJIMA, KOUJI BANNO, RYUICHIRO OKAWA, MEGUMI YANOKURA, MIHO IIDA, \\ TAKASHI TAKEDA, HARUKO KUNITOMI-IRIE, MASATAKA ADACHI, KANAKO NAKAMURA, \\ KIYOKO UMENE, YUYA NOGAMI, KENTA MASUDA, EIICHIRO TOMINAGA and DAISUKE AOKI \\ Department of Obstetrics and Gynecology, Keio University School of Medicine, Tokyo 160-8582, Japan
}

Received August 15, 2015; Accepted September 12, 2016

DOI: $10.3892 / 01.2017 .5582$

\begin{abstract}
Cancer typically develops due to genetic abnormalities, but a single gene abnormality cannot completely account for the onset of cancer. The Cancer Genome Atlas (CGA) project was conducted for the cross-sectional genome-wide analysis of numerous genetic abnormalities in various types of cancer. This approach has facilitated the identification of novel AT-rich interaction domain 1A gene mutations in ovarian clear cell carcinoma, frequent tumor protein 53 (TP53) gene mutations in high-grade ovarian serous carcinoma, and Kirsten rat sarcoma and B-rapidly accelerated fibrosarcoma proto-oncogene, serine/threonine kinase gene mutations in low-grade ovarian serous carcinoma. Genome-wide analysis of endometrial cancers has led to the establishment of four subgroups: Polymerase ultramutated, microsatellite instability hypermutated, genome copy-number low and genome copy-number high. These results may facilitate the improvement of the prediction of patient prognosis and therapeutic sensitivity in various types of gynecologic cancer. The enhanced use of currently available therapeutic agents and the development of novel drugs may be facilitated by the novel classification of ovarian cancer based on TP53 mutations, the efficacy of poly (ADP-ribose) polymerase inhibitors for tumors with breast cancer $1 / 2$ mutations and the effect of phosphoinositide-3-kinase (PI3K)/mammalian target of rapamycin inhibitors for tumors with mutations in the PI3K/protein kinase $\mathrm{B}$ signaling pathway. Important results have been revealed by genome-wide analyses; however, the pathogenic underlying mechanisms of gynecologic cancer will require further studies and multilateral evaluation using epigenetic, transcriptomic and proteomic analyses, in addition to genomic analysis.
\end{abstract}

Correspondence to: Dr Kouji Banno, Department of Obstetrics and Gynecology, Keio University School of Medicine, Shinanomachi 35 Shinjuku-ku, Tokyo 160-8582, Japan

E-mail:kbanno@z7.keio.jp

Key words: Cancer Genome Atlas, ovarian cancer, endometrial cancer, AT-rich interaction domain 1A, tumor protein 53

\section{Contents}

1. Introduction

2. Genomic analysis in ovarian clear cell carcinoma

3. Genomic analysis in ovarian high-grade serous carcinoma

4. Genomic analysis in ovarian low-grade serous carcinoma

5. Genomic analysis in endometrial cancer

6. Classification of ovarian cancer based on genome-wide analysis and clinical application

7. Clinical application of the results from genomic analysis

8. Conclusion

\section{Introduction}

In the early 20th century, chromosomal abnormalities were considered to cause carcinogenesis (1). The subsequent identification of various oncogenes and tumor-suppressor genes demonstrated that cancer develops due to genetic abnormalities (2,3); however, single-gene abnormalities are insufficient to explain the malignant transformation of all types of cancer, which are hypothesized to require a combination of numerous genetic abnormalities (4). To investigate the underlying mechanisms of cancer development, a human genome-wide analysis study was proposed in 1986, and the Human Genome Project was conducted from 1990 to 2003 (5). Genome-wide analyses of various types of cancer have subsequently increased due to the widespread use of next-generation sequencers (6).

Genome-wide analyses have revealed that B-rapidly accelerated fibrosarcoma proto-oncogene, serine/threonine kinase $(B R A F)$ and phosphatidylinositol-4,5-bisphosphate 3-kinase, catalytic subunit $\alpha(P I K 3 C A)$ are frequently expressed in melanoma and rectal cancer, respectively $(7,8)$, and that epidermal growth factor receptor genetic abnormalities may occur in lung cancers (9-11). The Cancer Genome Atlas (CGA) project was conducted in the USA and has collected data on 12 types of cancer (cervical cancer, cholangiocarcinoma, esophageal carcinoma, liver hepatocellular carcinoma, mesothelioma, pancreatic ductal adenocarcinoma, paraganglioma and pheochromocytoma, sarcoma, testicular germ cell cancer, thymoma, uterine carcinosarcoma and uveal melanoma) since 2006 till 2012. The objective of the CGA was to conduct comprehensive analyses of complete genomes for various 
types of cancer and to compare them with normal human genomes, with the aim of identifying the presence of genetic abnormalities in each type of cancer (12). The CGA aims to conduct further analyses in other types of cancer in order to determine characteristic and common genetic abnormalities among various types of cancer (13).

Data from the tumor genomes of several hundred patients with ovarian cancer, brain tumors or squamous cell lung cancer, and comparative data from normal genomes, have been analyzed in the CGA (14-16). These results were published in 2009, and formed the basis for the Pan-Cancer Analysis Project, which began in 2012 (17). In that study on 5,074 patients, the exomes of 12 types of cancer were analyzed, including bladder urothelial carcinoma, breast and colon cancers, head and neck squamous cell carcinoma, renal clear cell carcinoma, acute myeloid leukemia, lung adenocarcinoma, squamous cell lung cancer, and ovarian, rectal and endometrial cancer (17). Comprehensive genome-wide analysis was used to identify common or independent molecular characteristics among these types of cancer (18). Regarding gynecologic cancers, all exomes of ovarian clear cell carcinoma were analyzed in 2010, and the results of the genomic analyses of ovarian serous carcinoma and endometrial cancer were published in 2011 and 2013, respectively $(19,20)$.

\section{Genomic analysis in ovarian clear cell carcinoma}

Ovarian clear cell carcinoma accounts for $8.4 \%$ of all ovarian cancers worldwide (21). Mutations in the PIK3CA gene were identified to occur in $\sim 33 \%$ of cases of ovarian clear cell carcinoma (22). Tan et al identified protein kinase B 2 (AKT2) gene amplifications in certain clear cell carcinomas, and demonstrated its involvement in patient prognosis (23). The CGA identified a number of frequent mutations in the AT-rich interactive domain 1A (ARIDIA) gene, which is located on chromosome 1q36 and encodes Brahma/SWI2-related gene 1-associated factor 250 (24). The transcription product of the ARIDIA gene is a component of the SWItch/sucrose non-fermentable chromatin remodeling complex (25), which alters the nucleosomal structure and regulates DNA-binding proteins in an adenosine triphosphate-dependent manner (26). Therefore, abnormalities in these complexes may cause abnormalities in DNA transcription, replication and repair, and may result in the malignant transformation of cells. Abnormalities in this specific component protein have been frequently identified in patients with ovarian clear cell carcinoma, particularly at International Federation of Gynecology and Obstetrics stages III and IV, and in patients with high cancer antigen 125 expression levels (27).

In order to examine the messenger RNA (mRNA) expression pattern in clear cell carcinoma, 400 gene groups with differential expression profiles specific to clear cell carcinoma were selected, and the signature of ovarian clear cell carcinoma was identified (28). Mutations in hepatocyte nuclear factor-1 $\beta$ (29) and ARIDIA (24) are currently considered to be important for occurrence of clear cell carcinoma, and numerous genes that are associated with the ovarian clear cell carcinoma signature are involved in stress response, glucose metabolism and coagulation, which are three key signaling pathways in clear cell carcinoma (30). Numerous patients with clear cell adenocarcinoma originally present with endometriosis, which suggests that the microenvironment in endometriosis includes signaling factors that may be involved in the development of this type of cancer (28). In a typical case of endometriosis, high levels of free iron are observed, which may generate reactive oxygen species (31). In addition, the oxidative stress levels are high, and cell dysfunction and DNA damage are common (31). Stress response genes are often highly expressed in patients with clear cell adenocarcinoma who originally had endometriosis, which indicates that the stress response signaling pathway may be involved in the development of clear cell carcinoma from endometriosis (28).

\section{Genomic analysis in ovarian high-grade serous carci- noma}

Serous carcinoma accounts for $\sim 52.4 \%$ of all cases of ovarian cancer (21), and $>90 \%$ of serous carcinomas are highly malignant (19). In a genomic analysis of 489 patients with high-grade serous ovarian cancer (HGSOC) published in 2011 (21), the CGA demonstrated that the tumor protein 53 (TP53) gene was mutated at a rate of $\sim 96 \%$, and genetic abnormalities were identified in $87 \%$ of TP53-associated signaling molecules, including the TP53 gene-related forkhead box protein M1 (FOXM1) gene (19). In normal non-cancerous cells, TP53 inactivates FOXM1 in the presence of DNA damage (32). Therefore, TP53 mutations induce an increase in FOXMI expression and subsequent abnormal signaling (33). Three isoforms of FOXM1, FOXM1c, FOXM1b and FOXM1s, are involved in cell proliferation and DNA repair $(34,35)$, and the effects of TP53 genetic mutations on these signaling molecules have been hypothesized to cause malignant transformation in cells (36).

Brachova et al identified numerous types of functionally significant TP53 mutations, and classified these mutations into four types, as follows: Oncomorphic, loss of function, unclassified and wild type (37). Oncomorphic mutations in endometrial cancer and HGSOC were detected in $21.2 \%$ of high-grade serous carcinomas, and these cases were associated with poorer progression-free survival (PFS), higher risk of recurrence $(\sim 60 \%)$ and greater resistance to platinum-based drugs, as compared with the other three groups (37). However, unclassified TP53 mutations account for $~ 59.1 \%$ of cases of high-grade serous carcinomas (38), and the numerous effects of these mutations have yet to be elucidated.

In serous ovarian cancer, the incidence of mutation is also frequent $(\sim 22 \%)$ for the breast cancer $1 / 2(B R C A 1 / 2)$ gene (39). BRCA is involved in homologous recombination and thus, mutations in this gene may cause defects in DNA repair mechanisms (40). Abnormal homologous recombination has been identified in $\sim 50 \%$ of cells with BRCA mutations (41). Mutations in BRCA2-interacting transcriptional repressor (EMSY; 8\%), phosphatase and tensin homolog (PTEN; 7\%), RAD51 paralog C (3\%) and Fanconi anemia complementation group D2 (5\%) have also been identified in various serous carcinomas (19).

A DNA copy number analysis was also performed in the CGA, as chromosomal instability is a characteristic of high-grade serous carcinoma (42). High-grade serous 
carcinoma has more changes in DNA copy number than other tissue types of epithelial ovarian cancer (43). DNA copy number abnormalities in HGSOC include amplification of the v-myc avian myelocytomatosis viral oncogene homolog $(M Y C)$ and cyclin E1 (CCNE1) genes, as well as BRCA defects, a number of which are considered to be involved in patient prognosis (44). The CGA analysis identified complex DNA copy number abnormalities in $>1 / 2$ of the patients involved (19), with chromosomal regions including CCNE1, $M Y C$ and MDS1 and EVI1 complex locus protein EVI1 being highly amplified in $>20 \%$ of tumors (45). Five specific amplified genes were identified, including the activated C-kinase receptor zinc finger MYND-type containing 8, the p53 target gene interferon regulatory factor 2 binding protein 2 , the DNA-binding protein inhibitor inhibitor of differentiation 4 , the embryonic development gene paired box 8 and the telomerase catalytic subunit telomerase reverse transcriptase (TERT) (19).

The results of the analysis described above indicate that $>20$ gene abnormalities may occur in high-grade serous adenocarcinoma, and that these are often identified in certain signaling molecules, including retinoblastoma, PI3K/AKT, neurogenic locus notch homolog and FOXM1 (46).

\section{Genomic analysis in ovarian low-grade serous carcino- ma}

An analysis of low-grade serous carcinoma was performed in 2012 (47). Somatic mutations in Kirsten rat sarcoma $(K R A S)$ and $B R A F$ have been identified in low-grade serous carcinoma at an incidence of $\sim 65 \%$ (48). BRAF mutations may occur in patients without concurrent KRAS mutations, in various types of cancer, which suggests that KRAS and BRAF have complementary functions in the activation of the mitogen-activated protein kinase (MAPK) signaling pathway (49). The CGA aimed to identify novel gene abnormalities, but only KRAS and BRAF mutations were revealed in cases of low-grade serous carcinoma (50). In cases of high-grade serous carcinoma, abnormalities were identified in the PI3K/AKT signaling molecules, whereas abnormalities in the KRAS/BRAF signaling molecules were present in low-grade serous carcinoma (51). Therefore, genetic abnormality in cell growth regulators may induce malignant transformation in high- and low-grade serous carcinomas, but the effect of abnormalities in the underlying signaling pathways may vary.

\section{Genomic analysis in endometrial cancer}

Endometrioid carcinoma accounts for $\sim 84 \%$ of endometrial cancers (21), and estrogen stimulation is an established risk factor (52). Both serous carcinoma and clear cell carcinoma are estrogen-independent endometrial cancers of type II (53). In 2013, the CGA published a comprehensive genomic analysis of 373 patients with these two types of endometrial cancer (54), and a novel classification of endometrial cancers was proposed based on genomic alterations, in contrast to the conventional classification system based on tissue type and estrogen stimulation (55). The novel classification system is based on polymerase $\varepsilon$ (POLE) gene abnormalities, microsatellite instability (MSI) and chromosomal copy number, and includes four subgroups, as follows: POLE ultramutated, MSI hypermutated, genome copy-number low and genome copy-number high (Fig. 1).

Patients included in the POLE ultramutated subgroup are positive for POLE gene abnormalities, but negative for MSI. Patients in this subgroup have a good disease-free survival rate and, therefore, a favorable prognosis. Patients included in the MSI hypermutated subgroup are MSI-positive and also have frequent gene mutations. The genome copy-number low subgroup is MSI-negative and has a low frequency of DNA copy number abnormalities. The copy-number high subgroup has a TP53 gene mutation rate of $>90 \%$, and includes a number of patients with serous adenocarcinoma (Table I) (56-58).

ARIDIA mutations have been observed to occur in $>40 \%$ of subjects in the other three subgroups, and mutations in KRAS and PTEN are also common in these three subgroups. Mutation of the PI3K pathway-related phosphatidylinositol-3-kinase regulatory subunit 1 gene occurs at a high frequency in all four subgroups. Mutations in other types of cancer often involve the components of the receptor tyrosine kinase (RTK)/RAS/PI3K signaling pathway; however, mutations in endometrial cancer are typically associated with the RTK/RAS/ $\beta$-catenin (CTTNB1) and PI3K signaling pathways, with mutation rates differing among the four subgroups. Therefore, KRAS and fibroblast growth factor receptor 2 (FGFR2) mutations are common in the MSI subgroup; $\beta$-catenin, SRY-box 17 and FGFR2 mutations frequently occur in the genome copy-number low subgroup; and Erb-B2 receptor tyrosine kinase 2 gene amplifications and F-box and WD repeat domain containing $\beta 7$ ( $F B X W 7$ ) mutations occur in the genome copy-number high subgroup (59).

Among uterine serous carcinoma, somatic mutations in TP53, PIK3CA and FBXW7 were identified (57). Gene amplification of $C C N E 1$ was identified in $50 \%$ of cases (60). Amplification increases the CCNE1 expression levels, whereas FBXW7-mediated ubiquitination of CCNE1 reduces its expression levels (61). Therefore, the mutation or amplification of these genes causes certain abnormalities in the cell cycle that may result in carcinogenesis (62).

Ring finger protein 43 (RNF43) mutations are common in pancreatic cystic neoplasms and are also observed in endometrial cancer (60). RNF43 encodes an E3 ubiquitin ligase, and negatively regulates Wnt signaling (63). The genomes of 248 subjects with endometrial cancer from the CGA were identified to have RNF43 mutations at a rate of $18.1 \%$ (63). RNF43 mutations increase Wnt signaling, which increases cell proliferation and causes carcinogenesis (64). RNF43 mutations are frequently identified in MSI-positive tumors, and these mutations are present in $\sim 50.7 \%$ of subjects with endometrial cancer with MSI (65). CTNNB1, MYC and CCND1 are also involved in the activation of Wnt signaling, and the overexpression of these genes decreases overall survival in patients with endometrial cancer (66).

A recent CGA analysis demonstrated high expression levels of TERT and cleft lip and palate transmembrane protein 1-like protein in endometrial cancer (67). TERT is highly expressed in DNA copy number-stable cancers, including thyroid carcinoma (68), and in endometrial cancer with a low genome copy number (69). 
Table I. Frequency of gene mutations in endometrial cancer, as determined by genome-wide analysis (revised from reference 57 for TP53, KRAS, PI3K, FBXW7/CCNE1 and PTEN; and 58 for ARIDIA and PTEN).

\begin{tabular}{lcccrr}
\hline Gene name & $\begin{array}{c}\text { POLE } \\
\text { ultramutated, } \%\end{array}$ & $\begin{array}{c}\text { MSI } \\
\text { hypermutated, } \%\end{array}$ & $\begin{array}{c}\text { Copy-number } \\
\text { low, } \%\end{array}$ & $\begin{array}{c}\text { Copy-number } \\
\text { high, } \%\end{array}$ & $\begin{array}{c}\text { Serous } \\
\text { carcinoma, } \%\end{array}$ \\
\hline ARID1A & $>70$ & $>30$ & $>40$ & $<10$ & 6.0 \\
TP53 & $>30$ & $<10$ & $<10$ & $>0$ & 4.4 \\
KRAS & $>50$ & $>30$ & $>10$ & $>10$ & 50 \\
PI3K & $>70$ & $>50$ & $>50$ & $>20$ & 50.0 \\
FBXW7/CCNE1 & $>80$ & $>10$ & $>10$ & $<10$ & 17.0 \\
PTEN & $>90$ & $>80$ & $>0$ & \\
\hline
\end{tabular}

POLE, polymerase $\varepsilon$; MSI, microsatellite instability; ARID1A, AT-rich interactive domain 1A; TP53, tumor protein 53; KRAS, Kirsten rat sarcoma; PI3K, phosphoinositide-3-kinase; FBXW7, F-Box and WD repeat domain containing 7; CCNE1, cyclin E1; PTEN, phosphatase and tensin homolog.

Table II. Frequency of gene mutations in ovarian cancer by tissue type (revised from reference 22 for $P I 3 K 3 ; 25$ for ARIDIA; 39 for BRCA; 50 for KRAS; and 71 and 93 for TP53).

\begin{tabular}{lcc}
\hline Gene name & HGSC, $\%$ & CCC, $\%$ \\
\hline ARID1A & 0 & 57.0 \\
TP53 & 96 & 52.0 \\
BRCA & 22 & 6.3 \\
KRAS & 0 & 14.0 \\
PI3K3 & $<10$ & 33.0 \\
\hline
\end{tabular}

ARID1A, AT-rich interactive domain 1A; TP53, tumor protein 53; $K R A S$, Kirsten rat sarcoma; $P I 3 K$, phosphoinositide-3-kinase; $B R C A$, breast cancer; HGSC, high-grade serous carcinoma; CCC, clear cell carcinoma.

\section{Classification of ovarian cancer based on genome-wide analysis and clinical application}

Analyses of ovarian and endometrial cancers reveal common gene abnormalities, despite tumor development in various tissues, whereas gene abnormalities may differ in certain types of cancer that develop in the same tissues (Tables I and II) (70). In ovarian cancer, TP53 mutations occur in $96 \%$ of high-grade serous adenocarcinoma cases (71). HGSOC has a poor prognosis (63), which previously led to the proposal to classify ovarian cancer according to the type of gene mutation, rather than the tissue type (71). In the proposed classification, type I includes low-grade serous adenocarcinoma, low-grade endometrioid carcinoma, clear cell carcinoma and serous carcinoma, which have infrequent TP53 mutations, while type II includes high-grade serous carcinoma, undifferentiated cancer and carcinosarcoma, which have frequent TP53 mutations (72). The classification according to the frequency of TP53 mutations facilitates screening and therapy (73), and may allow the development of personalized treatments.

Previous studies have proposed that HGSOC develops in the fallopian tube $(44,74)$. The fallopian tube tissues in patients with ovarian cancer have been revealed to contain
BRCA mutation-positive carcinoma in situ, which is referred to as serous tubal intraepithelial carcinoma (STIC) (75). STIC has frequent TP53 mutations $(44,74)$, which suggests that the engraftment of STIC cells from the fallopian tube on to the ovarian surface may induce the development of ovarian cancer.

\section{Clinical application of the results from genomic analysis}

Novel treatments targeting specific gene abnormalities have been developed based on the CGA results. In a previous study, 6-12 cycles of platinum-based adjuvant chemotherapy were administered following tumor debulking in 60 patients with ovarian clear cell adenocarcinoma and 17 patients with high-grade serous adenocarcinoma (27). An evaluation of prognosis and ARID1A expression levels demonstrated that the PFS in the ARID1A-negative group was significantly shorter, as compared with that in the ARID1A-positive group $(\mathrm{P}<0.01)$, indicating a resistance to platinum-based chemotherapy in the absence of ARID1A (27). Therefore, the results of genome-wide analysis revealed the mechanisms underlying the variation in chemoresistance among these patients. Current chemotherapeutic strategies for ovarian cancer are determined based on the disease stage; however, conventional chemotherapy may be disadvantageous for certain patients, and treatment may be more effectively selected based on the presence of specific gene mutations.

Poly (ADP-ribose) polymerase (PARP) inhibitors for BRCA1/2 are currently being developed as novel anticancer drugs targeting tumors with gene abnormalities (76). PARP is activated following DNA damage, and repairs single-stranded DNA by polymerization of adenosine diphosphate-ribose residues (77). In the absence of DNA repair by PARP, double-stranded DNA is repaired by BRCA1/2 (78). In tumors with $B R C A 1 / 2$ mutations, the use of PARP inhibitors eliminates all DNA repair mechanisms, inducing an antitumor effect via the promotion of cell death $(79,80)$. The CGA identified numerous BRCA1/2 mutations in HGSOC, and olaparib, a PARP inhibitor, has been examined in a phase II clinical trial in patients with this disease (81). Trials using a combination of current chemotherapeutic agents for ovarian cancer and olaparib are also in progress $(82,83)$. 


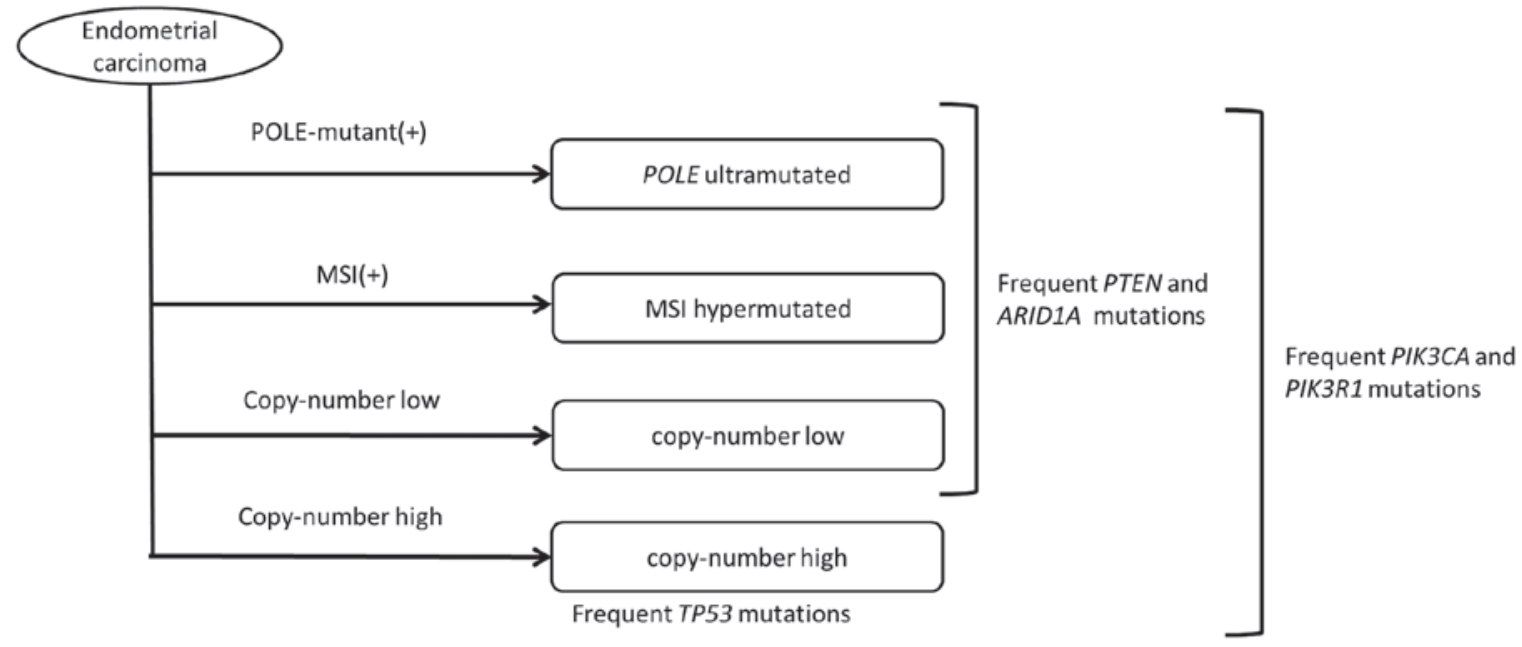

Figure 1. Classification and characteristics of endometrial cancer, as determined by genome-wide analysis. The novel classification of endometrial cancer is based on POLE gene abnormalities, MSI and chromosomal copy number. POLE gene-positive subjects are classified into the POLE ultramutated group and MSI-positive subjects are classified into the MSI hypermutated group. Those patients with a low or high chromosomal copy number are classified into the copy-number low and high groups, respectively. POLE, polymerase $\varepsilon$; MSI, microsatellite instability; TP53, tumor protein 53; PTEN, phosphatase and tensin homolog; ARID1A, AT-rich interactive domain 1A; PIK3CA, phosphatidylinositol-4,5-bisphosphate 3-kinase, catalytic subunit $\alpha$; PIK3R1, phosphatidylinositol-3-kinase regulatory subunit 1.

Thus, the treatment of ovarian cancer may improve due to the enhanced understanding of the genetic abnormalities involved in this disease.

$\mathrm{PI} 3 \mathrm{~K} /$ mechanistic target of rapamycin (mTOR) inhibition may be effective for the treatment of HGSOC and endometrial cancer with mutations in the PI3K/AKT signaling pathway. mTOR is a serine/threonine kinase that regulates cell proliferation (84). Certain gene mutations increase mTOR expression levels, resulting in abnormal cell proliferation (84). Hypoxia-inducible factor $1 \alpha$ is located downstream of mTOR, and is involved in angiogenesis; thus, mTOR overexpression enhances cell proliferation and vasa vasorum neovascularization (85-87). Anticancer drugs targeting mTOR include everolimus, an mTOR inhibitor used to treat renal cell carcinoma (88). Gene analysis of ovarian cancer tissues revealed mTOR mutations, therefore suggesting the effectiveness of mTOR inhibitors in ovarian cancer (88-90). In mice with subcutaneously implanted human ovarian clear cell carcinoma cells, the tumor size was halved following treatment with everolimus, Taxol ${ }^{\circledR}$ and cisplatin (86). When everolimus was administered alone, the tumor size did not decrease, but cellular apoptosis was observed (86).

As previously described, DNA copy number abnormalities occur at a high rate in type II HGSOC, with amplification of $\geq 22$ oncogenes (19). Therefore, specific gene abnormalities are present in numerous signaling pathways in high-grade serous adenocarcinoma (91). A molecular-targeted drug may only inhibit one signaling pathway and thus, conventional chemotherapy may be required to obtain a good therapeutic effect (92). Trials of novel drugs that are able to simultaneously inhibit PI3K and mTOR have also been conducted $(93,94)$. These include a phase I study on the use of DS-7423 for the treatment of ovarian cancer and a phase I study on the use of NVP-BEZ235 for the treatment of endometrial cancer, in which, the efficacy of NVP-BEZ235 was compared with that of everolimus (94).
Ovarian low-grade serous carcinoma also has poor sensitivity to standard chemotherapy $(95,96)$. In this disease, KRAS and BRAF are important in the MAPK signaling pathways, and the MAPK kinase inhibitor selumetinib has an antitumor effect $(97,98)$. A phase II study demonstrated a response rate of $15.4 \%$, a disease progression-control rate of $80.8 \%$ and a median PFS of 11.0 months (98). In contrast to HGSOC, the low-grade type of serous ovarian carcinoma has relatively lower DNA copy number, and the underlying mechanism of carcinogenesis may depend on a single signaling pathway (99). Therefore, the efficacy of specific molecular-targeted drugs is consistent with the CGA analysis.

\section{Conclusion}

CGA analyses of gene mutations have provided novel classifications and the foundation for therapy selection based on gene abnormalities. Epigenetic mutations include those in microRNAs (miRNAs or miRs) (100-102), which are small RNA molecules containing 22 nucleotides that induce gene silencing $(102,103)$. In gynecologic cancers, the downregulation of specific miRNAs, including miR-30c and miR-152, is involved in the onset of cancer $(104,105)$. These miRNAs downregulate the expression of certain oncogenes, including discoidin domain receptor and latent transforming growth factor- $\beta$ binding protein- 4 ; therefore, decreased expression of these miRNAs results in tumorigenesis (106). Further analyses of epigenetic changes, including those associated with miRNAs, are required for comparison with the analyses of gene mutations.

The causes of gene mutations also require further evaluation. The CGA results indicate that the apolipoprotein B mRNA editing enzyme catalytic polypeptide-like 3B (APOBEC3B) is a cause of certain gene mutations (107-109), with a $\mathrm{C}$ - $\mathrm{T}$ base substitution rate identified to be more frequent than other substitutions in numerous types of cancer, 
including bladder and lung cancer (110). APOBEC3B is overexpressed in cancer cells with frequent $\mathrm{C}-\mathrm{T}$ base substitutions, which suggests that APOBEC 3B may be associated with genome mutations (108).

The genome-wide analyses in the CGA project have detected common abnormalities in various types of cancer (109). However, only 12 types of cancer have been analyzed to date, and the CGA aims to analyze a further 50 types of cancer through extended data collection (109). Genome-wide analyses were initially intended to determine the mechanisms underlying the development of cancer; however, the pathogenic mechanisms have yet to be elucidated, despite the important information previously obtained on gene abnormalities (17). Epigenetic data, including those for miRNAs, and proteomic analyses have revealed that carcinogenesis depends on numerous other factors in addition to gene abnormalities (110). These results indicate that further understanding of the pathogenic mechanisms underlying cancer will require numerous genomic, epigenetic, transcriptomic and proteomic studies, including current genome, miRNA expression, DNA methylation and reverse-phase protein array analyses.

\section{Acknowledgements}

The authors thank Dr S. Takizawa (Keio University School of Medicine, Tokyo, Japan) and Dr A. Chida (Keio University School of Medicine, Tokyo, Japan) for their helpful assistance. The present study was supported by the Keio Gijuku Academic Development Fund (Tokyo, Japan).

\section{References}

1. Boveri T: On multipolar mitosis as a means of analysis of the cell nucleus. Neu Folge 35: 67-90, 1902.

2. Stehelin D, Varmus HE, Bishop JM and Vogt PK: DNA related to the transforming gene(s) of avian sarcoma viruses is present in normal avian DNA. Nature 260: 170-173, 1976.

3. Tabin CJ, Bradley SM, Bargmann CI, Weinberg RA, Papageorge AG, Scolnick EM, Dhar R, Lowy DR and Chang EH: Mechanism of activation of a human oncogene. Nature 300: 143-149, 1982

4. Vogelstein B, Fearon ER, Hamilton SR, Kern SE, Preisinger AC, Leppert M, Nakamura Y, White R, Smits AM and Bos JL: Genetic alterations during colorectal-tumor development. N Engl J Med 319: 525-532, 1988.

5. Dulbecco R: A turning point in cancer research: Sequencing the human genome. Science 231: 1055-1056, 1986.

6. Wright CF, Fitzgerald TW, Jones WD, Clayton S, McRae JF, van Kogelenberg M, King DA, Ambridge K, Barrett DM, Bayzetinova T, et al: Genetic diagnosis of developmental disorders in the DDD study: A scalable analysis of genome-wide research data. Lancet 385: 1305-1314, 2015.

7. Davies H, Bignell GR, Cox C, Stephens P, Edkins S, Clegg S, Teague J, Woffendin H, Garnett MJ, Bottomley W, et al: Mutations of the BRAF gene in human cancer. Nature 417: 949-954, 2002.

8. Samuels Y, Wang Z, Bardelli A, Silliman N, Ptak J, Szabo S, Yan H, Gazdar A, Powell SM, Riggins GJ, et al: High frequency of mutations of the PIK3CA gene in human cancers. Science 304: $554,2004$.

9. Lynch TJ, Bell DW, Sordella R, Gurubhagavatula S, Okimoto RA, Brannigan BW, Harris PL, Haserlat SM, Supko JG, Haluska FG, et al: Activating mutations in the epidermal growth factor receptor underlying responsiveness of non-small-cell lung cancer to gefitinib. N Engl J Med 350: 2129-2139, 2004.

10. Paez JG, Jänne PA, Lee JC, Tracy S, Greulich H, Gabriel S, Herman P, Kaye FJ, Lindeman N, Boggon TJ, et al: EGFR mutations in lung cancer: Correlation with clinical response to gefitinib therapy. Science 304: 1497-1500, 2004.
11. Pao W, Miller V, Zakowski M, Doherty J, Politi K, Sarkaria I, Singh B, Heelan R, Rusch V, Fulton L, et al: EGF receptor gene mutations are common in lung cancers from 'never smokers' and are associated with sensitivity of tumors to gefitinib and erlotinib. Proc Natl Acad Sci USA 101: 13306-13311, 2004.

12. Akbani R, Ng PK, Werner HM, Shahmoradgoli M, Zhang F, Ju Z, Liu W, Yang JY, Yoshihara K, Li J, et al: A pan-cancer proteomic perspective on The Cancer Genome Atlas. Nat Commun 5: 3887, 2014

13. The future of cancer genomics. Nat Med 21: 99, 2015.

14. Garraway LA and Lander ES: Lessons from the cancer genome. Cell 153: 17-37, 2013.

15. Vogelstein B, Papadopoulos N, Velculescu VE, Zhou S, Diaz LA Jr and Kinzler KW: Cancer genome landscapes. Science 339: 1546-1558, 2013.

16. Wheeler DA and Wang L: From human genome to cancer genome: The first decade. Genome Res 23: 1054-1062, 2013.

17. Cancer Genome Atlas Research Network, Weinstein JN, Collisson EA, Mills GB, Shaw KR, Ozenberger BA, Ellrott K, Shmulevich I, Sander C and Stuart JM: The cancer genome atlas pan-cancer analysis project. Nat Genet 45: 1113-1120, 2013.

18. Kong J, Cooper LA, Wang F, Gutman DA, Gao J, Chisolm C, Sharma A, Pan T, Van Meir EG, Kurc TM, et al: Integrative, multimodal analysis of glioblastoma using TCGA molecular data, pathology images and clinical outcomes. IEEE Trans Biomed Eng 58: 3469-3474, 2011.

19. Cancer Genome Atlas Research Network: Integrated genomic analyses of ovarian carcinoma. Nature 474: 609-615, 2011.

20. Cancer Genome Atlas Research Network, Kandoth C, Schultz N, Cherniack AD, Akbani R, Liu Y, Shen H, Robertson AG, Pashtan I, Shen R, et al: Integrated genomic characterization of endometrial carcinoma. Nature 497: 67-73, 2013.

21. Heintz AP, Odicino F, Maisonneuve P, Quinn MA, Benedet JL, Creasman WT, Ngan HY, Pecorelli S and Beller U: Carcinoma of the ovary. FIGO 26th annual report on the results of treatment in gynecological cancer. Int J Gynaecol Obstet 95 (Suppl 1): S161-S192, 2006

22. Kuo KT, Mao TL, Jones S, Veras E, Ayhan A, Wang TL, Glas R, Slamon D, Velculescu VE, Kuman RJ and Shih IeM: Frequent activating mutations of PIK3CA in ovarian clear cell carcinoma. Am J Pathol 174: 1597-1601, 2009.

23. Tan DS, Iravani M, McCluggage WG, Lambros MB, Milanezi F Mackay A, Gourley C, Geyer FC, Vatcheva R, Millar J, et al: Genomic analysis reveals the molecular heterogeneity of ovarian clear cell carcinomas. Clin Cancer Res 17: 1521-1534, 2011

24. Jones S, Wang TL, Shih IeM, Mao TL, Nakayama K, Roden R, Glas R, Slamon D, Diaz LA Jr, Vogelstein B, et al: Frequent mutations of chromatin remodeling gene ARID1A in ovarian clear cell carcinoma. Science 330: 228-231, 2010.

25. Wiegand KC, Shah SP, Al-Agha OM, Zhao Y, Tse K, Zeng T, Senz J, McConechy MK, Anglesio MS, Kalloger SE, et al: ARID1A mutations in endometriosis-associated ovarian carcinomas. N Engl J Med 363: 1532-1543, 2010.

26. Mohrmann L and Verrijzer CP: Composition and functional specificity of SWI2/SNF2 class chromatin remodeling complexes. Biochim Biophys Acta 1681: 59-73, 2005.

27. Katagiri A, Nakayama K, Rahman MT, Rahman M, Katagiri H, Nakayama N, Ishikawa M, Ishibashi T, Iida K, Kobayashi H, et al: Loss of ARID1A expression is related to shorter progression-free survival and chemoresistance in ovarian clear cell carcinoma. Mod Pathol 25: 282-288, 2012.

28. Yamaguchi K, Mandai M, Oura T, Matsumura N, Hamanishi J, Baba T, Matsui S, Murphy SK and Konishi I: Identification of an ovarian clear cell carcinoma gene signature that reflects inherent disease biology and the carcinogenic processes. Oncogene 29: 1741-1752, 2010.

29. Tsuchiya A, Sakamoto M, Yasuda J, Chuma M, Ohta T, Ohki M, Yasugi T, Taketani Y and Hirohashi S: Expression profiling in ovarian clear cell carcinoma: Identification of hepatocyte nuclear factor-1 beta as a molecular marker and a possible molecular target for therapy of ovarian clear cell carcinoma. Am J Pathol 163: 2503-2512, 2003.

30. Yamaguchi K, Huang Z, Matsumura N, Mandai M, Okamoto T, Baba T, Konishi I, Berchuck A and Murphy SK: Epigenetic determinants of ovarian clear cell carcinoma biology. Int $\mathrm{J}$ Cancer 135: 585-597, 2014.

31. Yamaguchi K, Mandai M, Toyokuni S, Hamanishi J, Higuchi T, Takakura K and Fujii S: Contents of endometriotic cysts, especially the high concentration of free iron, are a possible cause of carcinogenesis in the cysts through the iron-induced persistent oxidative stress. Clin Cancer Res 14: 32-40, 2008. 
32. Barger CJ, Zhang W, Hillman J, Stablewski AB, Higgins MJ, Vanderhyden BC, Odunsi K and Karpf AR: Genetic determinants of FOXM1 overexpression in epithelial ovarian cancer and functional contribution to cell cycle progression. Oncotarget 6 : 27613-27627, 2015.

33. Barsotti AM and Prives C: Pro-proliferative FOXM1 is a target of p53-mediated repression. Oncogene 28: 4295-4305, 2009.

34. Ma RY, Tong TH, Cheung AM, Tsang AC, Leung WY and Yao KM: Raf/MEK/MAPK signaling stimulates the nuclear translocation and transactivating activity of FOXM1c. J Cell Sci 118: 795-806, 2005

35. Tan Y, Raychaudhuri P and Costa RH: Chk2 mediates stabilization of the FOXM1 transcription factor to stimulate expression of DNA repair genes. Mol Cell Biol 27: 1007-1016, 2007.

36. Lane DP: Cancer. p53, guardian of the genome. Nature 358: $15-16,1992$

37. Brachova P, Mueting SR, Carlson MJ, Goodheart MJ, Button AM, Mott SL, Dai D, Thiel KW, Devor EJ and Leslie KK: TP53 oncomorphic mutations predict resistance to platinum- and taxane-based standard chemotherapy in patients diagnosed with advanced serous ovarian carcinoma. Int J Oncol 46 : 607-618, 2015.

38. Brachova P, Mueting SR, Devor EJ and Leslie KK: Oncomorphic TP53 mutations in gynecologic cancers lose the normal protein: Protein interactions with the microRNA microprocessing complex. J Cancer Ther 5: 506-516, 2014.

39. Liu G, Yang D, Sun Y, Shmulevich I, Xue F, Sood AK and Zhang W: Differing clinical impact of BRCA1 and BRCA2 mutations in serous ovarian cancer. Pharmacogenomics 13: $1523-1535,2012$

40. Farmer H, McCabe N, Lord CJ, Tutt AN, Johnson DA, Richardson TB, Santarosa M, Dillon KJ, Hickson I, Knights C, et al: Targeting the DNA repair defect in BRCA mutant cells as a therapeutic strategy. Nature 434: 917-921, 2005.

41. Scully R, Puget $\mathrm{N}$ and Vlasakova K: DNA polymerase stalling, sister chromatid recombination and the BRCA genes. Oncogene 19: 6176-6183, 2000.

42. Kurman RJ and Shih IeM: Molecular pathogenesis and extraovarian origin of epithelial ovarian cancer: Shifting the paradigm. Hum Pathol 42: 918-931, 2011

43. Shah RH, Scott SN, Brannon AR, Levine DA, Lin O and Berger MF: Comprehensive mutation profiling by next-generation sequencing of effusion fluids from patients with high-grade serous ovarian carcinoma. Cancer Cytopathol 123: 289-297, 2015

44. Kurman RJ and Shih IeM: Molecular pathogenesis and extraovarian origin of epithelial ovarian cancer-shifting the paradigm. Hum Pathol 42: 918-931, 2011.

45. Wiedemeyer WR, Beach JA and Karlan BY: Reversing platinum resistance in high-grade serous ovarian carcinoma: Targeting BRCA and the homologous recombination system. Front Oncol 4: 34, 2014.

46. Rao SS, O'Neil J, Liberator CD, Hardwick JS, Dai X, Zhang T, Tyminski E, Yuan J, Kohl NE, Richon VM, et al: Inhibition of NOTCH signaling by gamma secretase inhibitor engages the RB pathway and elicits cell cycle exit in T-cell acute lymphoblastic leukemia cells. Cancer Res 69: 3060-3068, 2009.

47. Jones S, Wang TL, Kurman RJ, Nakayama K, Velculescu VE, Vogelstein B, Kinzler KW, Papadopoulos N and Shih IeM: Low-grade serous carcinomas of the ovary contain very few point mutations. J Pathol 226: 413-420, 2011.

48. Tothill RW, Tinker AV, George J, Brown R, Fox SB, Lade S, Johnson DS, Trivett MK, Etemadmoghadam D, Locandro B, et al: Novel molecular subtypes of serous and endometrioid ovarian cancer linked to clinical outcome. Clin Cancer Res 14: 5198-5208, 2008.

49. Rajagopalan H, Bardelli A, Lengauer C, Kinzler KW, Vogelstein B and Velculescu VE: Tumorigenesis: RAF/RAS oncogenes and mismatch-repair status. Nature 418: 934, 2002.

50. Singer G, Oldt R III, Cohen Y, Wang BG, Sidransky D, Kurman RJ and Shih IeM: Mutations in BRAF and KRAS characterize the development of low-grade ovarian serous carcinoma J Natl Cancer Inst 95: 484-486, 2003.

51. Kannan K, Coarfa C, Chao PW, Luo L, Wang Y, Brinegar AE, Hawkins SM, Milosavljevic A, Matzuk MM and Yen L: Recurren BCAM-AKT2 fusion gene leads to a constitutively activated AKT2 fusion kinase in high-grade serous ovarian carcinoma. Proc Natl Acad Sci USA 112: E1272-E1277, 2015

52. Buchanan EM, Weinstein LC and Hillson C: Endometrial cancer. Am Fam Physician 80: 1075-1080, 2009.
53. Setiawan VW, Yang HP, Pike MC, McCann SE, Yu H, Xiang YB, Wolk A, Wentzensen N, Weiss NS, Webb PM, et al: Type I and II endometrial cancers: Have they different risk factors? J Clin Oncol 31: 2607-2618, 2013

54. Matsumura N, Huang Z, Mori S, Baba T, Fujii S, Konishi I, Iversen ES, Berchuck A and Murphy SK: Epigenetic suppression of the TGF-beta pathway revealed by transcriptome profiling in ovarian cancer. Genome Res 21: 74-82, 2011.

55. Talhouk A, McConechy MK, Leung S, Li-Chang HH, Kwon JS, Melnyk N, Yang W, Senz J, Boyd N, Karnezis AN, et al: A clinically applicable molecular-based classification for endometrial cancers. Br J Cancer 113: 299-310, 2015.

56. Le Gallo M and Bell DW: The emerging genomic landscape of endometrial cancer. Clin Chem 60: 98-110, 2014

57. Garcia-Dios DA, Lambrechts D, Coenegrachts L, Vandenput I, Capoen A, Webb PM, Ferguson K, Akslen LA, Claes B, Vergote I, et al; Australian National Endometrial Cancer Study Group: High-throughput interrogation of PIK3CA, PTEN, KRAS, FBXW7 and TP53 mutations in primary endometrial carcinoma. Gynecol Oncol 128: 327-334, 2013.

58. Hoang LN, McConechy MK, Köbel M, Han G, Rouzbahman M, Davidson B, Irving J, Ali RH, Leung S, McAlpine JN, et al: Histotype-genotype correlation in 36 high-grade endometrial carcinomas. Am J Surg Pathol 37: 1421-1432, 2013.

59. Athanassiadou P, Athanassiades P, Grapsa D, Gonidi M, Athanassiadou AM, Stamati PN and Patsouris E: The prognostic value of PTEN, p53, and beta-catenin in endometrial carcinoma: A prospective immunocytochemical study. Int J Gynecol Cancer 17: 697-704, 2007.

60. Kuhn E, Wu RC, Guan B, Wu G, Zhang J, Wang Y, Song L, Yuan X, Wei L, Roden RB, et al: Identification of molecular pathway aberrations in uterine serous carcinoma by genome-wide analyses. J Natl Cancer Inst 104: 1503-1513, 2012.

61. Zhao S, Choi M, Overton JD, Bellone S, Roque DM, Cocco E, Guzzo F, English DP, Varughese J, Gasparrini S, et al: Landscape of somatic single-nucleotide and copy-number mutations in uterine serous carcinoma. Proc Natl Acad Sci USA 110: 2916-2921, 2013

62. Le Gallo M, O'Hara AJ, Rudd ML, Urick ME, Hansen NF, $\mathrm{O}^{\prime}$ Neil NJ, Price JC, Zhang S, England BM, Godwin AK, et al: Exome sequencing of serous endometrial tumors identifies recurrent somatic mutations in chromatin-remodeling and ubiquitin ligase complex genes. Nat Genet 44: 1310-1315, 2012.

63. Giannakis M, Hodis E, Jasmine Mu X, Yamauchi M, Rosenbluh J, Cibulskis K, Saksena G, Lawrence MS, Qian ZR, Nishihara R, et al: RNF43 is frequently mutated in colorectal and endometrial cancers. Nat Genet 46: 1264-1266, 2014.

64. Markowska A, Pawałowska M, Lubin J and Markowska J: Signalling pathways in endometrial cancer. Contemp Oncol (Pozn) 18: 143-148, 2014.

65. Jo YS, Kim MS, Lee JH, Lee SH, An CH and Yoo NJ: Frequent frameshift mutations in 2 mononucleotide repeats of RNF43 gene and its regional heterogeneity in gastric and colorectal cancers. Hum Pathol 46: 1640-1646, 2015.

66. Liu Y, Patel L, Mills GB, Lu KH, Sood AK, Ding L, Kucherlapati R, Mardis ER, Levine DA, Shmulevich I, et al: Clinical significance of CTNNB1 mutation and Wnt pathway activation in endometrioid endometrial carcinoma. J Natl Cancer Inst 106: dju245, 2014

67. Carvajal-Carmona LG, O'Mara TA, Painter JN, Lose FA, Dennis J, Michailidou K, Tyrer JP, Ahmed S, Ferguson K, Healey CS, et al: Candidate locus analysis of the TERT-CLPTM1L cancer risk region on chromosome 5p15 identifies multiple independent variants associated with endometrial cancer risk. Hum Genet 134: 231-245, 2015

68. Fredriksson NJ, Ny L, Nilsson JA and Larsson E: Systematic analysis of noncoding somatic mutations and gene expression alterations across 14 tumor types. Nat Genet 46: 1258-1263, 2014.

69. Oshita T, Nagai $\mathrm{N}$ and Ohama K: Expression of telomerase reverse transcriptase mRNA and its quantitative analysis in human endometrial cancer. Int J Oncol 17: 1225-1230, 2000.

70. Merritt MA and Cramer DW: Molecular pathogenesis of endometrial and ovarian cancer. Cancer Biomark 9: 287-305, 2010.

71. Erickson BK, Kinde I, Dobbin ZC, Wang Y, Martin JY, Alvarez RD, Conner MG, Huh WK, Roden RB, Kinzler KW, et al: Detection of somatic TP53 mutations in tampons of patients with high-grade serous ovarian cancer. Obstet Gynecol 124: 881-885, 2014. 
72. McConechy MK, Ding J, Cheang MC, Wiegand KC, Senz J, Tone AA, Yang W, Prentice LM, Tse K, Zeng T, et al: Use of mutation profiles to refine the classification of endometrial carcinomas. J Pathol 228: 20-30, 2012.

73.Parkinson DR, Johnson BE and Sledge GW: Making personalized cancer medicine a reality: Challenges and opportunities in the development of biomarkers and companion diagnostics. Clin Cancer Res 18: 619-624, 2012.

74. Shih IeM and Kurman RJ: Ovarian tumorigenesis: A proposed model based on morphological and molecular genetic analysis Am J Pathol 164: 1511-1518, 2004.

75. Piek JM, van Diest PJ, Zweemer RP, et al: Dysplastic changes in prophylactically removed Fallopian tubes of women predisposed to developing ovarian cancer. J Pathol 195: 451-456, 2001.

76. Curtin N: PARP inhibitors for anticancer therapy. Biochem Soc Trans 42: 82-88, 2014

77. Cass I, Baldwin RL, Varkey T, Moslehi R, Narod SA and Karlan BY: Improved survival in women with BRCA-associated ovarian carcinoma. Cancer 97: 2187-2195, 2003.

78. Ashworth A: A synthetic lethal therapeutic approach: Poly (ADP) ribose polymerase inhibitors for the treatment of cancers deficient in DNA double-strand break repair. J Clin Oncol 126: 3785-3790, 2008

79. McCabe N, Turner NC, Lord CJ, Kluzek K, Bialkowska A, Swift S, Giavara S, O'Connor MJ, Tutt AN, Zdzienicka MZ, et al Deficiency in the repair of DNA damage by homologous recombination and sensitivity to poly(ADP-ribose) polymerase inhibition. Cancer Res 66: 8109-8115, 2006.

80. Bryant HE, Schultz N, Thomas HD, Parker KM, Flower D, Lopez E, Kyle S, Meuth M, Curtin NJ and Helleday T: Specific killing of BRCA2-deficient tumours with inhibitors of poly(ADP-ribose) polymerase. Nature 434: 913-917, 2005.

81. Gelmon KA, Tischkowitz M, Mackay H, Swenerton K, Robidoux A, Tonkin K, Hirte H, Huntsman D, Clemons M, Gilks B, et al: Olaparib in patients with recurrent high-grade serous or poorly differentiated ovarian carcinoma or triple-negative breast cancer: A phase 2, multicentre, open-label, non-randomised study. Lancet Oncol 12: 852-861, 2011.

82. Oza AM, Cibula D, Benzaquen AO, Poole C, Mathijssen RH, Sonke GS, Colombo N, Špaček J, Vuylsteke P, Hirte H, et al Olaparib combined with chemotherapy for recurrent platinum-sensitive ovarian cancer: A randomised phase 2 trial. Lancet Oncol 16: 87-97, 2015.

83. Lee JM, Hays JL, Annunziata CM, Noonan AM, Minasian L, Zujewski JA, Yu M, Gordon N, Ji J, Sissung TM, et al: Phase $\mathrm{I} / \mathrm{Ib}$ study of olaparib and carboplatin in BRCA1 or BRCA2 mutation-associated breast or ovarian cancer with biomarker analyses. J Natl Cancer Inst 106: dju089, 2014.

84. Fingar DC, Richardson CJ, Tee AR, Cheatham L, Tsou C and Blenis J: mTOR controls cell cycle progression through its cell growth effectors S6K1 and 4E-BP1/eukaryotic translation initiation factor 4E. Mol Cell Biol 24: 200-216, 2004.

85. Yuan TL and Cantley LC: PI3K pathway alterations in cancer: Variations on a theme. Oncogene 27: 5497-5510, 2008.

86.Zoncu R, Efeyan A and Sabatini DM: mTOR: From growth signal integration to cancer, diabetes and ageing. Nat Rev Mol Cell Biol 12: 21-35, 2011.

87.Engelman JA: Targeting PI3K signalling in cancer: Opportunities, challenges and limitations. Nat Rev Cancer 9 550-562, 2009.

88. Motzer RJ, Escudier B, Oudard S, Hutson TE, Porta C, Bracarda S, Grünwald V, Thompson JA, Figlin RA, Hollaender N, et al: Phase 3 trial of everolimus for metastatic renal cell carcinoma: Final results and analysis of prognostic factors. Cancer 116: 4256-4265, 2010.

89. Husseinzadeh N and Husseinzadeh HD: mTOR inhibitors and their clinical application in cervical, endometrial and ovarian cancers: A critical review. Gynecol Oncol 133: 375-381, 2014.

90. Hirasawa T, Miyazawa M, Yasuda M, Shida M, Ikeda M, Kajiwara H, Matsui N, Fujita M, Muramatsu T and Mikami M: Alterations of hypoxia-induced factor signaling pathway due to mammalian target of rapamycin (mTOR) suppression in ovarian clear cell adenocarcinoma: In vivo and in vitro explorations for clinical trial. Int J Gynecol Cancer 23: 1210-1218, 2013.

91. Köbel M, Huntsman D and Gilks CB: Critical molecular abnormalities in high-grade serous carcinoma of the ovary. Expert Rev Mol Med 10: e22, 2008

92.Zoratto F, Rossi L, Giordani E, Strudel M, Papa A and Tomao S: From conventional chemotherapy to targeted therapy: Use of monoclonal antibodies (moAbs) in gastrointestinal (GI) tumors. Tumour Biol 35: 8471-8482, 2014
93. Kashiyama T, Oda K, Ikeda Y, Shiose Y, Hirota Y, Inaba K, Makii C, Kurikawa R, Miyasaka A, Koso T, et al: Antitumor activity and induction of TP53-dependent apoptosis toward ovarian clear cell adenocarcinoma by the dual PI3K/mTOR inhibitor DS-7423. PLoS One 9: e87220, 2014.

94. Shoji K, Oda K, Kashiyama T, Ikeda Y, Nakagawa S, Sone K, Miyamoto Y, Hiraike H, Tanikawa M, Miyasaka A, et al: Genotype-dependent efficacy of a dual PI3K/mTOR inhibitor, NVP-BEZ235 and an mTOR inhibitor, RAD001, in endometrial carcinomas. PLoS One 7: e37431, 2012

95. Gershenson DM, Sun CC, Bodurka D, Coleman RL, Lu KH, Sood AK, Deavers M, Malpica AL and Kavanagh JJ: Recurrent low-grade serous ovarian carcinoma is relatively chemoresistant. Gynecol Oncol 114: 48-52, 2009.

96. Gershenson DM, Sun CC, Lu KH, Coleman RL, Sood AK, Malpica A, Deavers MT, Silva EG and Bodurka DC: Clinical behavior of stage II-IV low-grade serous carcinoma of the ovary. Obstet Gynecol 108: 361-368, 2006.

97. Miller CR, Oliver KE and Farley JH: MEK1/2 inhibitors in the treatment of gynecologic malignancies. Gynecol Oncol 133: $128-137,2014$

98. Farley J, Brady WE, Vathipadiekal V, Lankes HA, Coleman R, Morgan MA, Mannel R, Yamada SD, Mutch D, Rodgers WH, et al: Selumetinib in women with recurrent low-grade serous carcinoma of the ovary or peritoneum: An open-label, single-arm, phase 2 study. Lancet Oncol 14: 134-140, 2013.

99. Kuo KT, Guan B, Feng Y, Mao TL, Chen X, Jinawath N, Wang Y, Kurman RJ, Shih IeM and Wang TL: Analysis of DNA copy number alterations in ovarian serous tumors identifies new molecular genetic changes inlow-grade and high-grade carcinomas. Cancer Res 69: 4036-4042, 2009.

100. Hamilton MP, Rajapakshe K, Hartig SM, Reva B, McLellan MD, Kandoth C, Ding L, Zack TI, Gunaratne PH, Wheeler DA, et al: Identification of a pan-cancer oncogenic microRNA superfamily anchored by a central core seed motif. Nat Commun 4: 2730, 2013.

101.Jacobsen A, Silber J, Harinath G, Huse JT, Schultz N and Sander C: Analysis of microRNA-target interactions across diverse cancer types. Nat Struct Mol Biol 20: 1325-1332, 2013.

102.Zovoilis A, Mungall AJ, Moore R, Varhol R, Chu A, Wong T, Marra $\mathrm{M}$ and Jones SJ: The expression level of small non-coding RNAs derived from the first exon of protein-coding genes is predictive of cancer status. EMBO Rep 15: 402-410, 2014

103. Mukherji S, Ebert MS, Zheng GX, Tsang JS, Sharp PA and van Oudenaarden A: MicroRNAs can generate thresholds in target gene expression. Nat Genet 43: 854-859, 2011.

104.Boren T, Xiong Y, Hakam A, Wenham R, Apte S, Wei Z, Kamath S, Chen DT, Dressman $\mathrm{H}$ and Lancaster JM: MicroRNAs and their target messenger RNAs associated with endometrial carcinogenesis. Gynecol Oncol 110: 206-215, 2008

105. Wu W, Lin Z, Zhuang Z and Liang X: Expression profile of mammalian microRNAs in endometrioid adenocarcinoma. Eur J Cancer Prev 18: 50-55, 2009

106. Mauel S, Kruse B, Etschmann B, von der Schulenburg AG, Schaerig M, Stövesand K, Wilcken B and Sterner-Kock A: Latent transforming growth factor binding protein 4 (LTBP-4) is downregulated in human mammary adenocarcinomas in vitro and in vivo. APMIS 115: 687-700, 2007.

107. Burns MB, Temiz NA and Harris RS: Evidence for APOBEC3B mutagenesis in multiple human cancers. Nat Genet 45: 977-983, 2013.

108. Roberts SA, Lawrence MS, Klimczak LJ, Grimm SA, Fargo D, Stojanov P, Kiezun A, Kryukov GV, Carter SL, Saksena G, et al: An APOBEC cytidine deaminase mutagenesis pattern is widespread in human cancers. Nat Genet 45: 970-976, 2013.

109. Cancer Genome Atlas Research Network, Weinstein JN, Collisson EA, Mills GB, Shaw KR, Ozenberger BA, Ellrott K, Shmulevich I, Sander C and Stuart JM: The cancer genome atlas pan-cancer analysis project. Nat Genet 45: 1113-1120, 2013.

110. Ren X, McHale CM, Skibola CF, Smith AH, Smith MT and Zhang L: An emerging role for epigenetic dysregulation in arsenic toxicity and carcinogenesis. Environ Health Perspect 119: 11-19, 2011. 